being discussed in parliament. Andronescu's actions reversed safeguards against conflicts of interest and cronyism. Andronescu did not respond with comment on these specific concerns in time for Nature's press deadline.

Under the latest rules, university rectors can once more be members of parliament, and academics over the retirement age of 65 , including Andronescu herself, can hold leadership positions at universities - previously banned to stop people holding on to power for too long. Funeriu had limited academics to supervising eight $\mathrm{PhD}$ students at a time - to stop powerful professors from dominating the training of the next generation - but that restriction has now been lifted. And grant applications no longer require review by scientists outside Romania.

In addition, Andronescu abolished the requirement that professors pass a special exam, and loosened Funeriu's minimum criteria for holding an academic post. Critics slam the new criteria as too soft, and say that they are distorted in some subjects - in biology, for example, the focus is on publication of books rather than of peer-reviewed papers. The loosened criteria were applied this year in appointing 1,300 professors as part of Romania's first competition for academic posts since 2009.

Andronescu, who remains a member of parliament, is now head of the senate's education committee and leads her university's senate. She told Nature that responsibility for developing minimum criteria for academic appointments lies with the Romanian National Council for the Attestation of University Titles. The criteria then become official through ministerial order.

Late last year, Andronescu was embroiled in further controversy, owing to accusations of plagiarism and copyright infringement in her research papers (see 'Plagiarism in politics').

Her ministerial successor, Mihnea Costoiu, told Nature that all procedures for academic appointments had been correctly followed in this year's hiring surge. He added that assertions that standards for becoming a professor had been lowered were "either a misinterpretation or an uninformed assumption on the part of the 'initiators' of this theory".

In April, Costoiu made deep retrospective cuts to the basic research budget, roughly halving the value of grants awarded in 2011 that were already in progress, and stalling the next round of already-evaluated grants. $\mathrm{He}$ also launched a new grant competition, for collaborations between research and industry, using laxer rules. Costoiu says that he intends ongoing grants to receive their full monies in later years.

In spite of the tumult, Ovidiu Sirbu remains optimistic. A grant that he applied for in 2012 finally came through this month, although it had been cut by about one-quarter. And he thinks that by staying, he can make a small difference to science in Romania. "One of the good things is that I can train people the way they should be trained," he says. "That's the best I can do now in this country." -

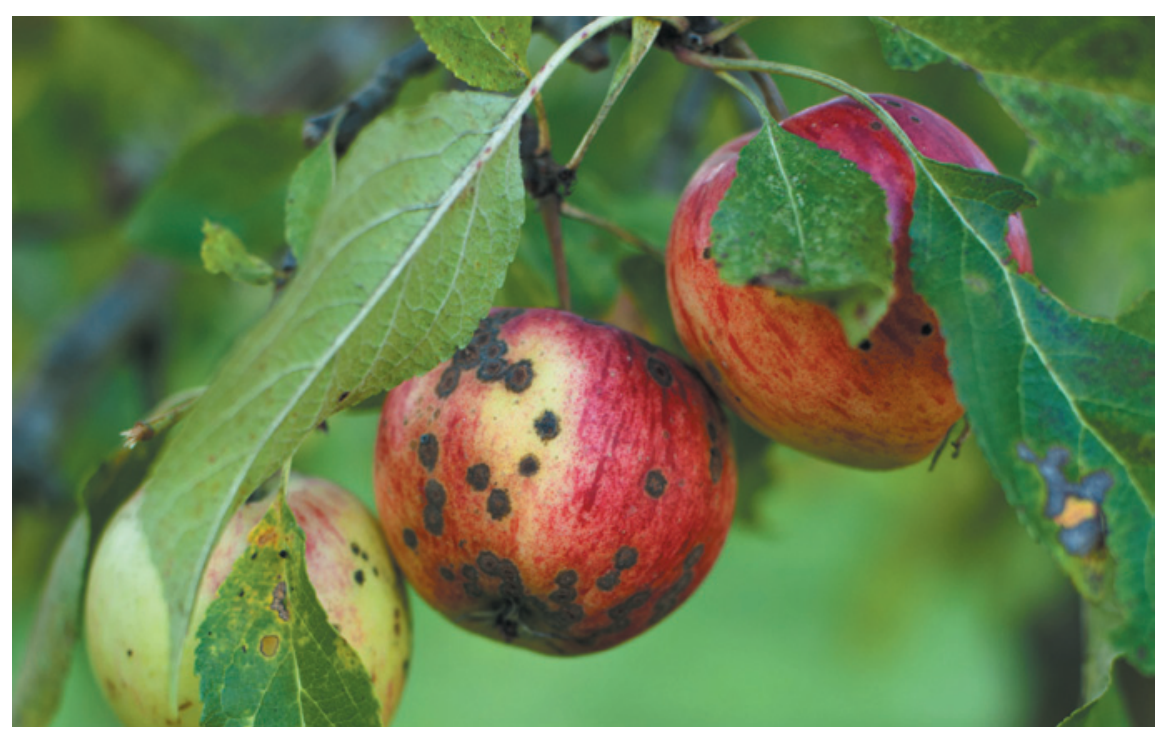

Apple scab is one of several crop diseases that researchers want to beat with genetic engineering.

\title{
BIOTECHNOLOGY
}

\section{US regulation misses some GM crops}

\section{Gaps in oversight of transgenic technologies allow scientists to test the waters for speciality varieties.}

\section{BY HEIDI LEDFORD}

$\mathrm{I}$ took scientists 85 years to breed a commercial apple that could fend off apple scab, a devastating disease caused by the fungus Venturia inaequalis. In 1999, they finally produced a tasty variety that contained the $V f$ defence gene, bred in from an unappetizing relative. Instead of dousing orchards with fungicides 30 times a season, farmers could spray the resistant crop just twice.

But five years later, $V$. inaequalis had evolved and apples trees were becoming infected again. Breeders were back to square one. Even armed with modern breeding techniques and 15 known defence genes in the apple family, it would take another 40 years to breed a resistant strain conventionally, says Henk Schouten, a plant scientist at Wageningen University in the Netherlands.

So instead, Schouten has joined a small but growing pool of academics and companies hoping to taking advantage of the latest approaches in genetic engineering, while avoiding the lengthy and expensive burden of government regulation. Because he wants to insert DNA only from related apple varieties, Schouten argues that his product should not be regulated in the same way as genetically modified (GM) crops that are engineered

with bacterial or viral DNA. Other pioneers argue that the techniques they are using to modify plants are safer than old technologies, and therefore do not need regulation. In some cases, US regulators have agreed.

Since 2010, the US Department of Agriculture has told at least 10 groups that their GM products would not require regulation (see 'Cropping out regulation') - removing a substantial financial barrier and speeding up development. That has encouraged academic labs and small companies to pursue speciality crops, such as apples, that have so far been ignored by biotechnology giants.

"There are any number of companies exploring new techniques to produce crops that don't trigger regulatory oversight," says Scott Thenell, managing director of Thenell \& Associates, a consulting firm in Walnut Creek, California, that helps researchers to navigate GM-plant regulations. "And often, they are small or niche crops that can't support the escalating costs of regulatory approval."

The regulation of GM crops in the United

DNATURE.COM For more on GM crops, see Nature's special issue: nature.com/gmcrops
States is based on laws that were not tailormade for the technology. The Animal and Plant Health Inspection Service (APHIS), 
- the branch of the agriculture department responsible for overseeing GM crops, has so far stuck to a strict interpretation of a 1957 law designed to protect agriculture against plant pests that was co-opted in 1986 to regulate GM crops. At that time, GM crops were nearly always engineered using Agrobacterium tumefaciens, a bacterial pest that can insert DNA into plant genomes.

In 2011, APHIS regulators announced that a herbicide-tolerant Kentucky bluegrass would not fall under their purview, because the lawn-and-garden company developing it did not use Agrobacterium or any other plantpest DNA to engineer the grass. The company, Scotts Miracle-Gro of Marysville, Ohio, instead used a gene gun to fire DNA-coated gold particles into plant cells. Some of that DNA is then incorporated into the genome.

For Greg Jaffe, director of biotechnology at the Center for Science in the Public Interest, a consumer advocacy group in Washington DC, the news highlighted the shortcomings of the US regulatory system for GM crops. "The whole system is a fiction," he says.

And some are starting to test the regulationfree waters. Scotts Miracle-Gro, for its part, has said that its bluegrass was not meant to be commercialized, and was just a test case to see how APHIS would respond. That is not the case for other groups that have been told that their GM products would not be regulated. Some include academic researchers, who are eager to avoid field-trial permits and special containment measures, and who want to encourage corporate development of niche crops.

Dennis Gray, a developmental biologist at the University of Florida in Apopka, is trying to use genes from grape varieties to engineer a wine grape that is resistant to Pierce's disease - a condition caused by a bacterium that has made it difficult to grow wine grapes in the state. He says that the lack of regulation is encouraging researchers like him to pursue such smallmarket crops. "Little agricultural labs just don't have access to the infrastructure and the money needed to move these forward."

Other emerging approaches may also escape regulation. Sally Mackenzie, a plant biologist at the University of Nebraska-Lincoln, contacted APHIS about the high-yield offspring of a transgenic sorghum grass plant - even though these offspring no longer contain the engineered gene. Mackenzie thinks that the transgene triggered

\section{CROPPING OUT REGULATION}

Since 2010, the US Department of Agriculture has told at least 10 groups that their genetically modified (GM) crops would not be regulated because a plant pest was not used to do the engineering.

\begin{tabular}{|c|c|c|c|}
\hline Crop & Trait & Developer & Technique \\
\hline Switchgrass & Easier conversion to biofuels & Ceres & Gene gun \\
\hline Grapes & Red colour & University of Florida & Gene gun \\
\hline Turf grasses & Herbicide tolerant & Scotts Miracle-Gro & Gene gun \\
\hline Maize (corn) & Improved nutrition & Dow AgroSciences & Zinc-finger nuclease \\
\hline Plums & Faster breeding & $\begin{array}{l}\text { Appalachian Fruit } \\
\text { Research Station }\end{array}$ & $\begin{array}{l}\text { Non-transgenic offspring } \\
\text { of GM parents }\end{array}$ \\
\hline Tobacco & Faster breeding & $\begin{array}{l}\text { North Carolina State } \\
\text { University }\end{array}$ & $\begin{array}{l}\text { Non-transgenic offspring } \\
\text { of GM parents }\end{array}$ \\
\hline Sorghum grass & Higher yields & $\begin{array}{l}\text { University of Nebraska- } \\
\text { Lincoln }\end{array}$ & Epigenetics \\
\hline Not disclosed & Faster breeding & $\begin{array}{l}\text { New Zealand Institute for } \\
\text { Plant and Food Research }\end{array}$ & $\begin{array}{l}\text { Non-transgenic offspring } \\
\text { of GM parents }\end{array}$ \\
\hline Ornamental plants & Not disclosed & BioGlow & Not disclosed \\
\hline Not disclosed & Not disclosed & Cellectis & $\begin{array}{l}\text { Meganuclease-targeted } \\
\text { gene deletions }\end{array}$ \\
\hline
\end{tabular}

an epigenetic change: it altered the plant's gene expression by changing the pattern of chemical groups added to its DNA rather than changing the DNA sequence itself. In 2012, APHIS regulators invited Mackenzie to the organization's headquarters in Riverdale, Maryland, and questioned her about this hypothesis. APHIS eventually notified her that it would not regulate her plants - a decision that Mackenzie says has accelerated her research and may allow her to launch a company to develop her grass variety.

Agricultural giants Monsanto, based in St Louis, Missouri, and Syngenta, headquartered in Basel, Switzerland, are vying to license the technology. "The first thing they asked me was, 'Have you been through APHIS?'” says Mackenzie.

Other companies are gauging their prospects with different DNA-modification tools, such as zinc-finger nucleases - enzymes that precisely target a region of the plant genome. In 2010, APHIS told Dow AgroSciences of Indianapolis, Indiana, that it would not regulate a herbicidetolerant maize (corn) made using zinc-finger nucleases. Dow spokesman Garry Hamlin says that the company has since dropped the maize project, but is working with outside researchers to develop other crops using similar technology. Jennifer Kuzma, a policy analyst at North Carolina State University in Raleigh, says that a lack of regulation for the latest approaches could fuel public suspicions about GM crops. “One could argue that the technologies are more targeted and you're doing things in a smarter way," she says. "The flip side is that they are so powerful you can engineer multiple genes at one time."

Not all companies are embracing the potential for freedom from regulation. Oliver Peoples, chief scientific officer at Metabolix, a plant-engineering company in Cambridge, Massachusetts, says that he would rather be regulated by APHIS to earn the public's trust. He notes that Agrobacterium inserts genes more efficiently than the gene-gun method. Although zinc-fingers are appealing for their specificity and their ability to escape regulation, companies do not yet have much experience in working with the technique, or navigating the patents needed to use it.

Schouten, meanwhile, did not skirt regulation for his apples after all. In April 2012, APHIS told him that the agency would regulate his variety in spite of the fact that the genes he introduced came from other apples. This was because he used Agrobacterium to insert the genes - it did not matter to regulators that no trace of Agrobacterium DNA remained in his plants.

Schouten is perplexed. If he had used a gene gun, he would have inserted DNA haphazardly and in a manner more likely to damage other sites in the genome - yet this remains the unregulated method. "To me, this is a very strange system," he says.

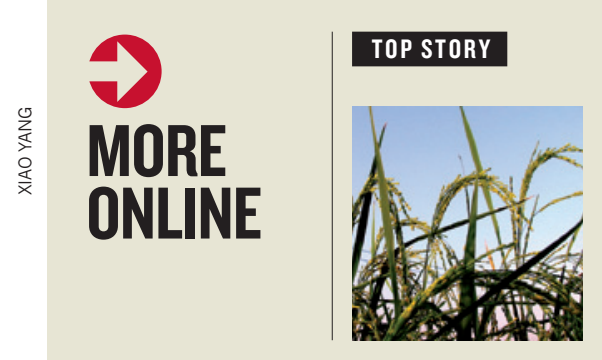

Pesticideresistance genes make weedy rice a worse pest go.nature. com/6swnpk

\section{MORE NEWS}

- Aquaculture farms cause subsidence in China's Yellow River delta go.nature.com/qmhtrc

- Measure of neural activity tracks waking states go.nature.com/dvfqll

- Climate change has made apples sweeter and softer go.nature.com/lzoikk

\section{NATURE PODCAST}

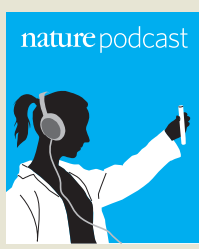

The 'sounds' of the stars; electric signals help plants heal; and turning skin cells into eggs and sperm nature. com/nature/podcast 